Research Article

\title{
Characteristics of Gravelly Granite Residual Soil in Bored Pile Design: An In Situ Test in Shenzhen
}

\author{
Shuai Luan $\left(\mathbb{D},{ }^{1}\right.$ Fenglai Wang $\mathbb{D},{ }^{1,2}$ Tiehong Wang, ${ }^{3}$ Zhao Lu, ${ }^{4}$ and Weihou Shui ${ }^{5}$ \\ ${ }^{1}$ School of Civil Engineering, Harbin Institute of Technology, Harbin 150090, China \\ ${ }^{2}$ Key Lab of Structures Dynamic Behavior and Control, Harbin Institute of Technology, Ministry of Education, \\ Harbin 150090, China \\ ${ }^{3}$ Chinese Construction Industry Association, Beijing 100081, China \\ ${ }^{4}$ Shenzhen Hongyeji Geotechnical Co., Ltd., Shenzhen 518055, China \\ ${ }^{5}$ China Zhonghua Geotechnical Engineering Group Co., Ltd., Beijing 102600, China
}

Correspondence should be addressed to Fenglai Wang; fl-wang@hit.edu.cn

Received 9 May 2018; Accepted 6 September 2018; Published 16 October 2018

Academic Editor: Md Mainul Islam

Copyright (c) 2018 Shuai Luan et al. This is an open access article distributed under the Creative Commons Attribution License, which permits unrestricted use, distribution, and reproduction in any medium, provided the original work is properly cited.

Granite residual soil is widely distributed in south China and is treated as a special soil. Its design parameters in rotary drilling bored piles are a matter of debate due to lack of in-situ pile load tests. Back-analysis of test piles is a reliable means of studying the geotechnical capacity of granite residual soil for pile design. In this study, a series of in situ tests was conducted comprising six fullscale instrumented test piles in gravelly granite residual soil in Shenzhen to consider the effects of different construction methods. The six piles were constructed with three different rotary drilling methods. Two commonly used design methods were investigated in the back-analysis: the SPT and effective stress methods. The results of the loading tests and strain gauges were used to obtain the back-analyzed parameters of the ultimate shaft resistance and ultimate base resistance for gravelly granite residual soil with these two design methods.

\section{Introduction}

Granite residual soil is a soil-like decomposed granite with weathering grades of VI, V, and IV. Classical "granite residual soil" is grade VI weathered granite and is distributed extensively in the tropical and subtropical areas of the world [1-3]. It is most widely distributed in southeast China, especially Guangdong Province, Fujian Province, and Hong Kong Special Administrative Region (HKSAR). These regions have a high economic output and large number of construction projects. The typical thickness of granite residual soil layer in these regions is $20-35 \mathrm{~m}$ and might be even up to $70 \mathrm{~m}$ in some areas [4-6]. High-rise buildings generally use pile foundations to support their loads. Thus, studying the characteristics of granite residual soil is very important for pile design.

Granite residual soil is generally classified as silty sand or sandy silt depending on the particle size distribution and according to the American Society for Testing and Materials (ASTM) and British Standards Institution (BSI) [7]. In China, it is generally considered to be clay according to GB50007 [8] and GB50021 [9]. Granite residual soil can also be divided into clayey soil, sandy clayey soil, and gravelly clayey soil according to the design code of Guangdong Province [10]; these correspond to gravel particles larger than $2 \mathrm{~mm}$ in diameter making up $0 \%, 0 \%-20 \%$, and $>20 \%$, respectively, of the content.

Previous studies have shown that granite residual soil is characterized by structural collapse induced by water inundation, and strength deterioration after disturbance $[7,11,12]$. Because its engineering characteristics are quite different from those of ordinary silt, clay, or sand, granite residual soil is treated as a special soil in China.

Bored piles are widely used in tall buildings all over the world because of the high load-bearing capacity and little noise pollution during construction. Since the 1980s, 
a number of studies have been carried out in South China that focused on bored piles in granite residual soil and weathered granite formations. However, no method has yet been developed for calculating the bearing capacity of bored piles in granite residual soil.

According to the Chinese national standard (JGJ-94 [13]) and local regulations of Guangdong Province (DBJ-15-31 [10]) and Fujian Province (DBJ-13-07 [14]), the bearing capacity of bored piles in granite residual soil can be estimated with the liquidity index $I_{\mathrm{L}}$ because it is treated as a kind of clay. The Shenzhen local standard (SJG01-2010) independently proposed a method for calculating the pile bearing capacity in granite residual soil by considering $I_{\mathrm{L}}$ [15]. In SJG01, the parameters of gravelly, sandy, and clayey granite residual soil were proposed, respectively, and higher resistance was proposed for higher content of gravel particles.

The effective stress and standard penetration test (SPT) methods are the most commonly used methods for pile design in the other country $[16,17]$ and are commonly used for pile design in granite residual soil in Hong Kong and Singapore [6, 18-21]. These two methods consider the vertical effective stress and SPT blow count $N$, respectively, in semiempirical formulas for the pile shaft and base resistances.

In the effective stress method, the average vertical effective stress is the main calculation parameter $[19,20]$. The coefficient $\beta$ is introduced to represent the relationship between the pile shaft resistance (or base resistance) and vertical effective stress. $\beta$ is a comprehensive coefficient that is affected by multiple factors, such as the soil density on the pile side, internal friction angle of the pile-soil interface, construction process, and pile material [22-24]. Ng et al. [19] proposed typical $\beta$ values for bored piles in granite saprolite constructed with different methods: the 95\% confidence range of $\beta$ is $0.2-0.4$ for piles constructed by grabbing/reverse circulation drilling (RCD) underwater with/without temporary casing, $0.4-0.8$ for piles postgrouted after construction by grabbing underwater with temporary casing, and 0.1-0.2 for piles constructed by RCD under bentonite. Fellenius et al. [20] proposed $\beta=1.0$ for the shaft resistance and $\beta=16$ for the base resistance to consider the residual load.

The SPT method is another most commonly used to estimate the pile bearing capacity. For bored piles in granite residual soil, the Geotechnical Engineering Office (GOE) [6] suggested the shaft resistance $\tau_{\mathrm{s}}=0.8-1.4 \mathrm{~N}$ for pile/soil settlement of about $1 \%$ the pile diameter and the base resistance is $6-13 N$ for a settlement of $1 \%$ the pile diameter. $\mathrm{Ng}$ et al. [19] proposed the following ratios of $\tau_{s} / N$ : $0.6-1.3$ for piles constructed underwater, 0.6-4.1 for postgrouted piles, and $0.0-1.3$ for piles constructed under bentonite. Chang and Broms [21] reported the ratio of $\tau_{\mathrm{s}} / N$ to range from 0.7 to 4 and suggested $\tau_{\mathrm{s}}=2 \mathrm{~N}$ for the design of bored piles constructed in residual soil in Singapore.

Although some studies have focused on the bearing capacity of bored piles in granite residual soil foundations, there still need some further studies. For example, although the Chinese specifications recommend forms of the $I_{\mathrm{L}}$ method $[10,13,15]$, and the calculation parameters for gravelly, sandy, and clayey granite residual soil were proposed, respectively, no parameter has been proposed for the SPT and effective stress methods. GEO, Ng et al., and Chang and Broms suggested coefficients for the SPT and effective stress methods; however, granite residual soil was not further classified in their studies, and these coefficients still need to be validated for Shenzhen. Moreover, the construction method has a great effect on the bearing capacity of piles. Brown [25], Chang and Zhu [26], and Ng et al. [19] presented construction factors for the shaft resistance, but the construction factor for the base resistance still needs further investigation.

Rotary drilling has been applied to the excavation of bored piles (drilled shafts) for decades and is widely used in China. It is generally performed with borehole support methods such as casing advanced ahead, bentonite slurry, and water. The characteristics of granite residual soil in bored piles constructed by rotary drilling are still needs further investigation.

Although some studies have focused on the bearing capacity of bored piles in granite residual soil foundations, further studies are still needed. The Chinese specifications recommend forms of the $I_{\mathrm{L}}$ method $[10,13,15]$; however, $I_{\mathrm{L}}$ value of granite residual soil is difficult to measure accurately. Therefore, Chinese engineering practicing needs effective stress and SPT methods such as alternative design methods and supplements to $I_{\mathrm{L}}$ method in bored pile design in granite residual soil area. In addition, granite residual soil was further classified as gravelly, sandy, and clayey granite residual soil in Chinese engineering practice, and gravelly granite residual soil has a higher bearing capacity [15]. The parameters of the SPT and effective stress methods should be further investigated, especially for gravelly granite residual soil that has a higher gravel content. Moreover, the construction method has a great effect on the bearing capacity of piles $[19,25,26]$. The construction factor for the different rotary drilling method in gravelly granite residual soil also needs further investigation.

In this study, a series of experiments was conducted to study the pile shaft resistance and pile base resistance of rotary drilling bored piles in gravelly granite residual soil (which can be classified as silty sand according to ASTM D2487 [27]), including six surveyed boreholes with SPT and borehole samples. A series of laboratory tests was carried out to build six full-size test piles. Three of the piles were constructed with a slurry retaining wall, three were constructed with casing advanced ahead, and all test piles were embedded with steel bar stress gauges. Six test piles were subjected to the static loaded test. The results were used to back-analyze the ultimate shaft and base resistances of these piles, and the parameters of granite residual soil with the SPT and effective stress methods were examined. Then, the influence of the construction method on the vertical bearing capacity of bored piles in granite residual soil was considered.

\section{Materials and Methods}

2.1. Test Layout. The test site was located in Shenzhen Institute for Drug Control in Keji Middle 1st Road, Nanshan 
District, Shenzhen, China, as shown in Figure 1. Six bored piles were constructed in the center of each test pile, and the SPT method was performed on six boreholes. Figure 2 shows the plan-view layout of the piles and boreholes.

The top $3 \mathrm{~m}$ was back-filled soil, followed by the granite weathering profile and granite bedrock. The back-filled layer was filled for more than 10 years and partially with broken bricks and concrete blocks. For the back-analysis, the soillike granite weathering profiles, which were granite residual soil at the macroscale, were treated as one unit. The groundwater level was at a depth of $7.5-9.5 \mathrm{~m}$ and was located at a depth between 7.6 and $7.8 \mathrm{~m}$ during the axial load tests of the testing piles.

\subsection{Materials}

2.2.1. Granite Residual Soil. Figure 3 shows the grain size distribution of the granite residual soil. The average content was $5.5 \%$ fine gravel, $23.3 \%$ coarse sand, $15.1 \%$ medium sand, $12.8 \%$ fine sand, and $43.7 \%$ silt and clay.

Table 1 shows the Atterberg limit test result of the granite residual soil. The Atterberg limit was obtained with the fall cone test. Test samples were made from original soil samples passed through a $0.5 \mathrm{~mm}$ sieve. For the granite residual soil, the plastic limit $w_{\mathrm{P}}$ was $21.5 \%-35.1 \%$ with an average value of $29.0 \%$ and the liquid limit $w_{\mathrm{L}}$ was $36.3 \%-61.9 \%$ with an average value of $52.8 \%$.

According to ASTM D2487 [27], the granite residual soil in this study can be classified as silty sand of ML to $\mathrm{MH}$ based on its grain size distribution and Atterberg limit. In Chinese engineering practice, however, granite residual soil is generally treated as a kind of special clayey soil because its engineering properties are quite different from those of sedimentary clay and sedimentary sand $[4,12]$. Table 2 presents the classification of granite residual soil (DBJ1531 [10] and SJG01 [15]). The residual soil in this research can be classified as gravelly clay.

2.2.2. Undrained Shear Strength of Granite Residual Soil. Because granite residual soil is generally treated as clay in China, its undrained shear strength $\left(S_{\mathrm{u}}\right)$ is determined with the quick direct shear box test and SPT. Figure 4 shows the results of the quick direct shear box test. The cohesion (c) was $9.5-35.3 \mathrm{kPa}$ with an average value of $22.4 \mathrm{kPa}$, while the internal friction angle $(\varphi)$ was $21.8^{\circ}-35.3^{\circ}$ with an average value of $28.0^{\circ}$.

Triaxial consolidated undrained (CU) tests were carried out in a prior geological investigation. For granite residual soil, the effective cohesion $\left(c^{\prime}\right)$ was taken as $13.7 \mathrm{kPa}$ and the effective internal friction angle $\left(\varphi^{\prime}\right)$ was taken as $30.8^{\circ}$.

\subsection{Experimental Setup}

2.3.1. Bored Pile Construction and Instrumentation. Rotary drilling is a kind of excavation method for largediameter bored piles. The borehole diameter is usually $0.6-4.0 \mathrm{~m}$. This method has been widely used in China in recent years because of its high efficiency and low pollution.
The rotary drilling machine can equip different kinds of drilling tools. In this study, a double-bottomed rotary drilling bucket was equipped; it is commonly used to excavate soil and decomposed rock. Pile excavation was conducted with the rotary drilling bucket. Excavated materials were loaded into the drilling bucket directly at the same time and then poured onto the ground.

Depending on the geological conditions, rotary drilling bored piles use different support methods to ensure that the borehole walls are safe and stable during excavation. The dry construction method without support is commonly used in hard soil or weathered rock above the groundwater level, but this method was not used in this study. When piles are bored in soft soil or the water level is relatively high, the borehole should be excavated with support by casing ahead, water, or drilling fluid. The drilling fluid can be a polymer or mineral (bentonite) fluid [25]. Unlike the traditional positive circulation and reverse circulation methods, the drilling fluid used in rotary drilling is relatively static because the fluid is not needed to transport excavated materials.

Six full-scale test piles were divided into two series based on two typical rotary drilling construction methods. Series 1 contained test piles TP-1 to TP- 3 that were constructed by rotary drilling with drilling fluid (RDF). The drilling fluid of TP1 and TP-2 was bentonite slurry and that of TP-3 was water. Series 2 contained test piles TP-4 to TP-6, and rotary drilling was conducted with casing advanced ahead (RDC). Figure 2 shows the test pile site. Figures 5(a)-(c) show the sketch of the six test piles, and Figure 5(d) shows the section of the test piles.

All six test piles were constructed with a nominal diameter of $1.0 \mathrm{~m}$. TP- 1 and TP- 4 had the same length of $8 \mathrm{~m}$, TP- 2 and TP- 5 had the same length of $18 \mathrm{~m}$, and TP- 3 and TP-6 had the same depth of $23 \mathrm{~m}$.

All piles were constructed with underwater concrete having a design compressive strength of $30 \mathrm{MPa}$. The reinforcing steel was composed of twenty $28 \mathrm{~mm}$ longitudinal bars extending to the full length and $8 \mathrm{~mm}$ hoops at a spacing of $0.2 \mathrm{~m}$. In the upper $2 \mathrm{~m}$, the hooping was $8 \mathrm{~mm}$ with a spacing of $0.1 \mathrm{~m}$ spacing. For each test pile, a reinforced concrete cap with an area of $1.5 \mathrm{~m} \times 1.5 \mathrm{~m}$ and thickness of $0.35 \mathrm{~m}$ was placed about 1 month after the piles were constructed.

In order to test the internal force of the pile during the test, all six test piles were instrumented with vibrating-wire strain gauges (VWSGs) and earth pressure cell (EPCs). The VWSGs were welded onto the steel cage of the test piles at several levels of spacing of 2-3 $\mathrm{m}$ in the vertical direction. At each level, four VWSGs were set. For TP-1 and TP-4, four levels of VWSGs were set; for TP-2 and TP-5, eight levels of VWSGs were set; and for TP- 3 and TP-6, 10 levels of VWSGs were set. For each test pile, four EPCs were set, and the EPC was attached to the bottom of the steel bar to which a VWSG was welded. The distance between the EPC and lower-level VWSG was $0.5 \mathrm{~m}$. The VWSGs and EPCs were checked before and after installation, after concreting, and before load testing.

2.3.2. Loading Test Procedures. In various test procedures used for pile load testing, the load-movement relationship 


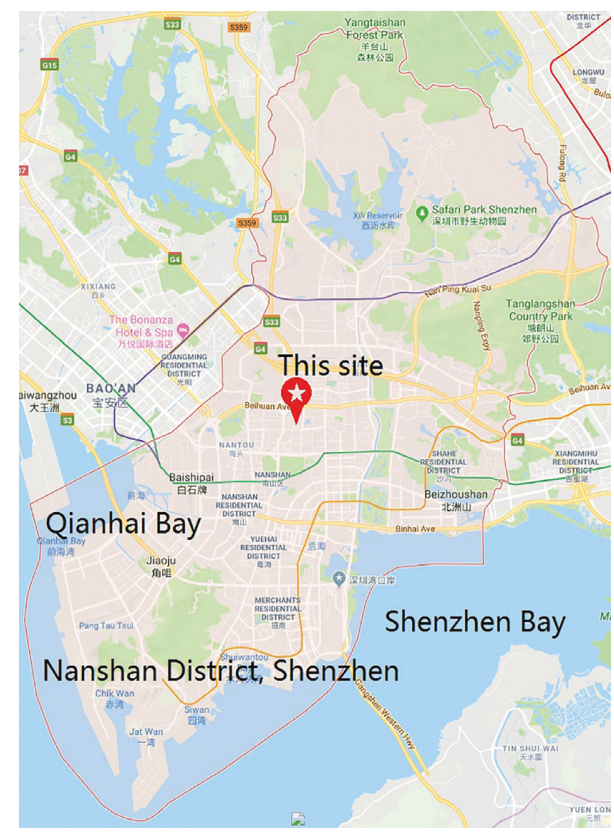

Figure 1: Location map of the experimental site.

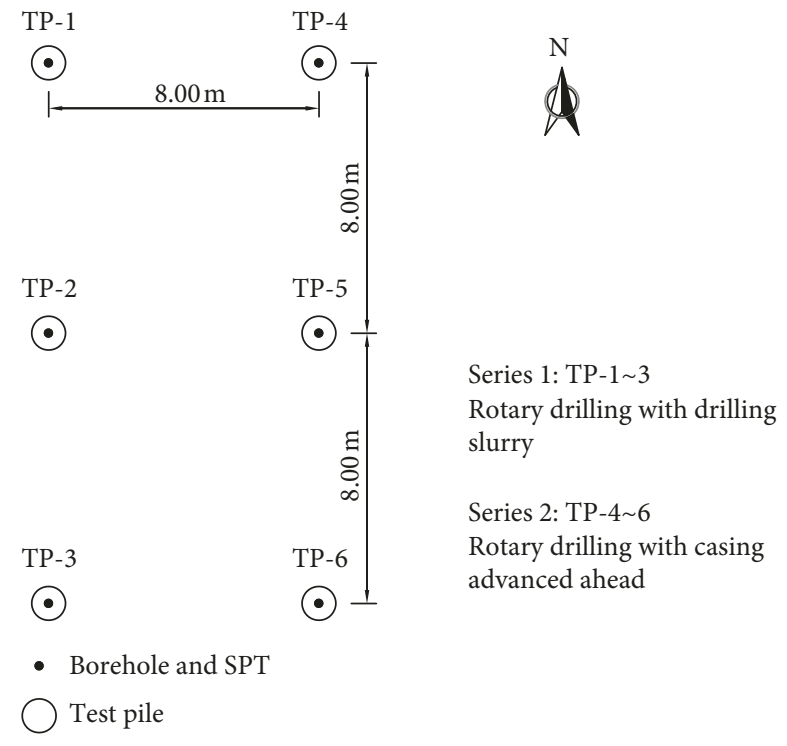

Figure 2: Layout of the test piles and boreholes.

produced by the slow maintained loading test (SMLT) method is the most similar to that which occurs during the construction process. In this study, all axial loading tests were carried out in accordance with the SMLT method (GB50007-2011 [8]). Note that the SMLT procedures of GB50007-2011 and ASTM D 1143/D 1143M-07 [28] differ in the criterion for applying the next load level. For GB500072011, the next load level cannot be applied until the rate of axial movement does not exceed $0.01 \mathrm{~mm} / \mathrm{h}$. For ASTM D $1143 / \mathrm{D} 1143 \mathrm{M}-07$, the rate is $0.25 \mathrm{~mm}(0.01 \mathrm{in}) / \mathrm{h}$ for a maximum of $2 \mathrm{~h}$.

In this study, the axial load was applied by using a reaction system consisting of four parts, as shown in Figure 6: the kentledge, load transmission beam, hydraulic jacks, and

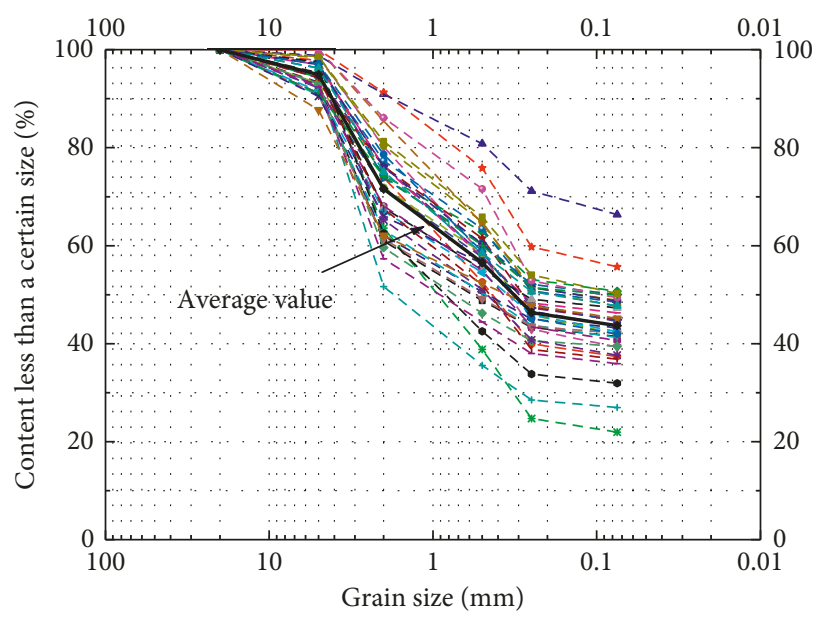

FIGURE 3: Soil grain size distribution of the granite residual soil.

TABle 1: The Atterberg limit test result of granite residual soil.

\begin{tabular}{lcc}
\hline Depth & Plastic limit, $w_{\mathrm{P}}(\%)$ & Liquid limit, $w_{\mathrm{L}}(\%)$ \\
\hline $3 \sim 6.5 \mathrm{~m}$ & $28.2 \sim 35.1$ & $55.3 \sim 61.9$ \\
$6.5 \sim 10 \mathrm{~m}$ & $26.6 \sim 31.6$ & $48.8 \sim 60.1$ \\
$10 \sim 13 \mathrm{~m}$ & $26.8 \sim 29.9$ & $47.0 \sim 57.4$ \\
$13 \sim 17 \mathrm{~m}$ & $26.3 \sim 33.2$ & $46.5 \sim 60.3$ \\
$17 \sim 22 \mathrm{~m}$ & $21.5 \sim 26.8$ & $36.3 \sim 49.2$ \\
Total & $21.5 \sim 35.1$ & $36.3 \sim 61.9$ \\
Mean value & 29.0 & 52.8 \\
\hline
\end{tabular}

TABle 2: Classification of granite residual soil in China.

\begin{tabular}{lc}
\hline Soil name & Content with $d \geq 2 \mathrm{~mm}$ \\
\hline Gravelly clay & More than $20 \%$ of the full weight \\
Sandy clay & Less than $20 \%$ of the full weight \\
Clay & None \\
\hline
\end{tabular}

automatic control system. The kentledge comprised stacked reinforced concrete blocks and was placed on the load transmission beam. Hydraulic jacks were placed under the load transmission beam used to apply load to the pile head.

The pile head settlement was tested with four linear variable differential transformers (LVDTs) that were placed symmetrically at the pile head. The applied load was tested with electronic pressure sensors in series on the hydraulic pump and confirmed with embedded strain gauges close to the jack.

Loading tests were carried out automatically with the RSJYC automatic control system produced by Wuhan Rocksea based on the data of the LVDTs and electronic pressure sensors.

In order to make the tested piles reach a very large pile head settlement to determine the ultimate bearing capacity of the tested piles, the maximum load was set to about three times the design working load.

\section{Results and Discussion}

3.1. Load-Settlement Response. Table 3 summarizes the loading test results. All of the test piles demonstrated very 

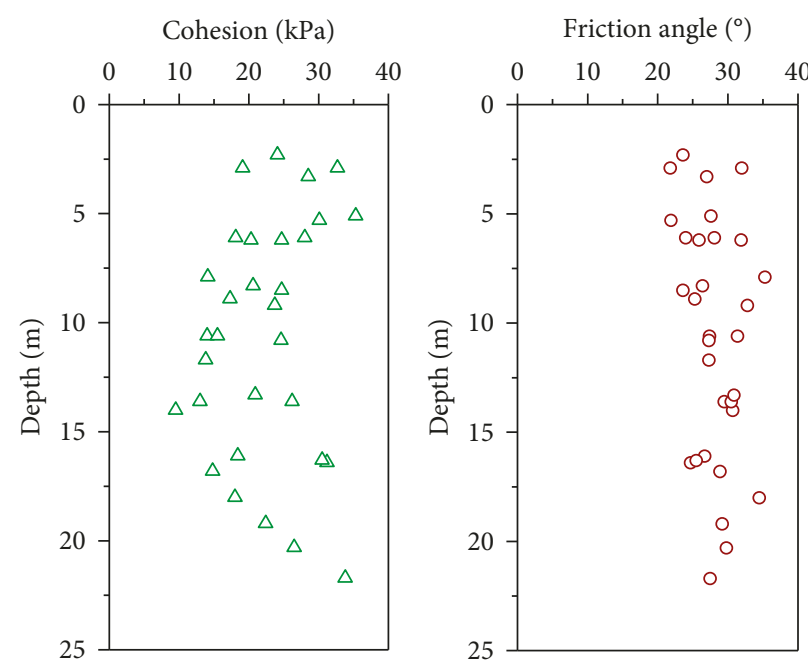

FIGURE 4: Relationships between the quick direct shear box test results and the depth.
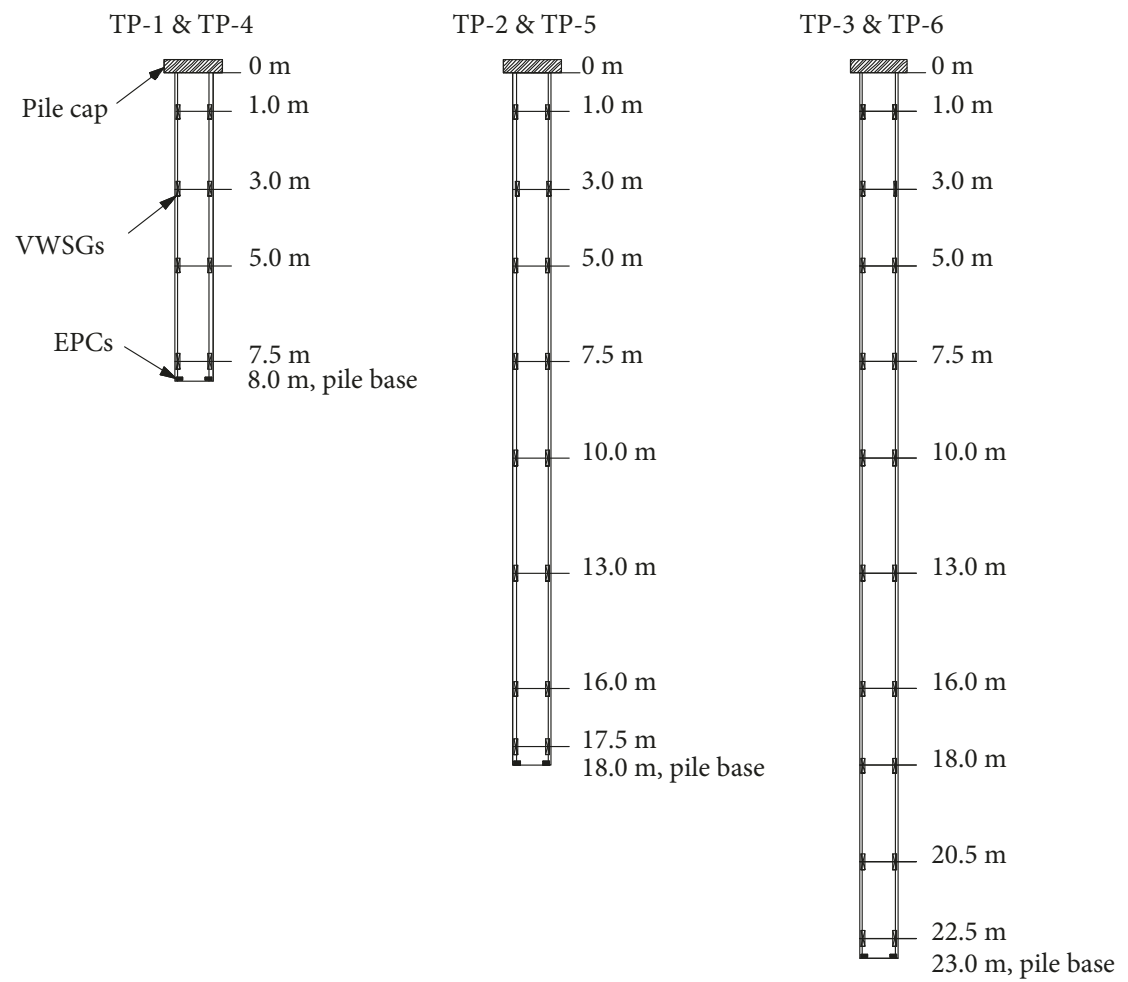

(a)

(b)

(c)

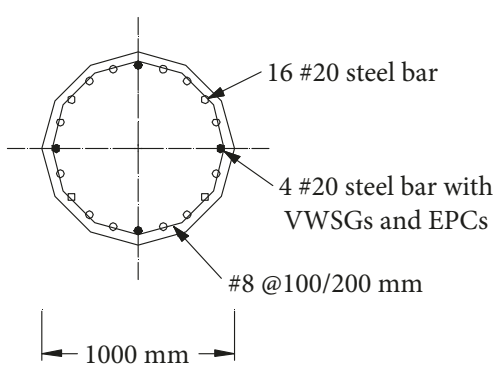

(d)

Figure 5: Sketch of the test piles. 


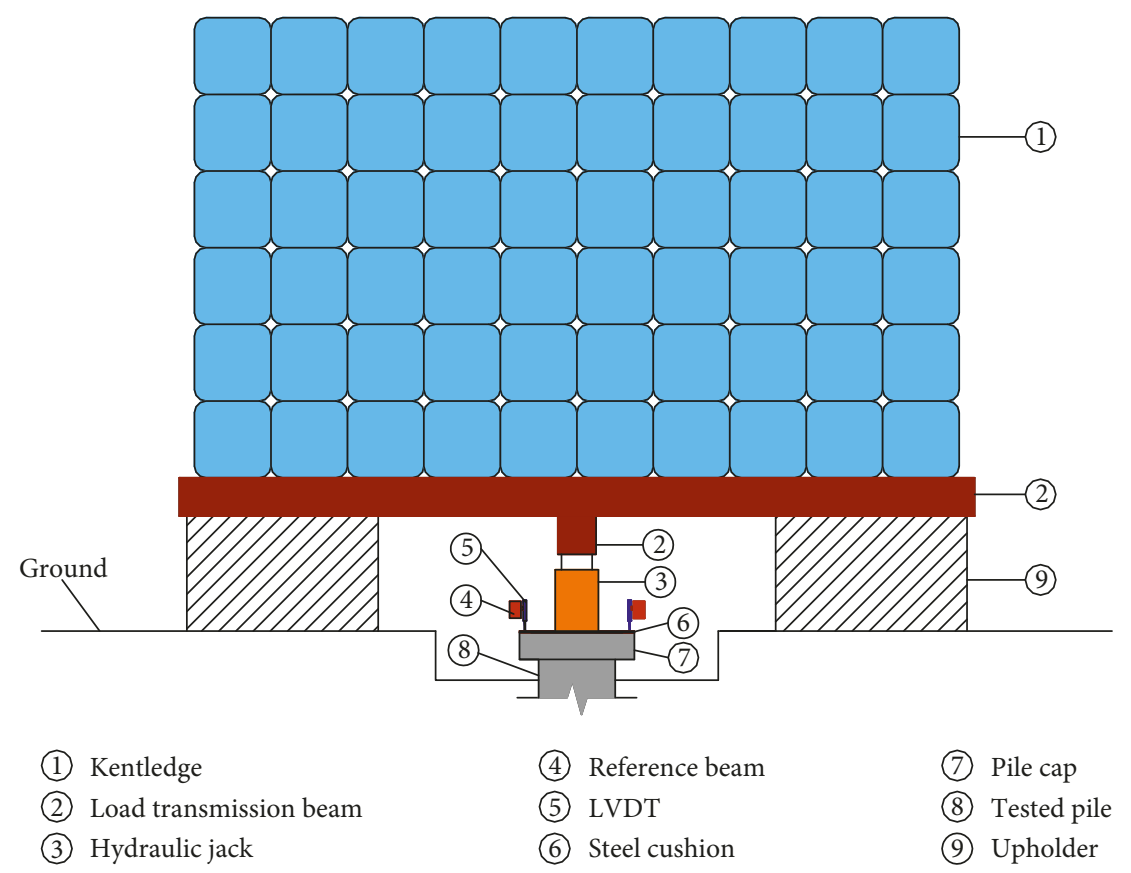

FIGURE 6: Schematic of the loading test reaction system.

large settlements of more than $50 \mathrm{~mm}$ at the end of the loading test. The test piles can be classified into three groups according to the pile length for comparison. Figure 7 compares the measured load-settlement responses at the pile head for each group. The piles constructed with casing advanced ahead (RDC) showed a higher ultimate resistance than piles constructed with drilling fluid (RDF). For all three groups, the load-settlement behaviors were rather similar up to the $100 \%$ design load with very little settlement (1.1$3.2 \mathrm{~mm}$ ). The differences became obvious at higher loads. This might be due to the microstructural properties of granite residual soil and the material characteristics of the bored piles. Granite residual soil subjected to shaft resistance is under shear, and granite residual soil subjected to base resistance is under compress. In this case, pile shaft resistance generally reaches the maximum value at a small pile head settlement, while pile base resistance generally reaches the maximum value at a higher settlement value. Moreover, pile shaft resistance mobilized ahead of pile base resistance, as the principle of load transfer of bored piles discussed by Zhang [29]. Thus, both pile head settlement and the deviation of each group are small at lower loads. With the applied loads increasing, settlement becomes larger, and the deviation becomes more significant due to the difference in the maximum value of the pile side resistance and the stiffness of the pile base resistance. These results agree with those of Lam et al. for the piles constructed with bentonite and polymer [30].

There are many methods for interpreting the failure load of a pile loading test [15]. In the literature, the critical failure load is taken as the load at a pile head settlement of $40 \mathrm{~mm}$, as stipulated by Chinese GB50007-2011. In this test, the largest settlement at a $200 \%$ design working load was $23.5 \mathrm{~mm}$ for all test piles. This is much smaller than the critical failure settlement, which means that the design loads were conservative.

The strain gauge results were analyzed to study the suitable design parameters of rotary drilling piles in granite residual soil in more detail, as discussed below.

3.2. Interpretation of the Strain Gauge Results. For each measurement section, the average value of four strain gauges was considered. The load of the $i$ th measurement section $\left(P_{i}\right)$ is calculated as follows:

$$
P_{i}=\left(E_{\mathrm{c}} A_{\mathrm{c}}+E_{\mathrm{s}} A_{\mathrm{s}}\right) \varepsilon_{i}
$$

where $E_{\mathrm{c}}$ is Young's modulus of concrete $\left(3.0 \times 10^{4} \mathrm{MPa}\right), A_{\mathrm{c}}$ is the section area of concrete, $E_{\mathrm{s}}$ is Young's modulus of the steel bar $\left(2.0 \times 10^{5} \mathrm{MPa}\right), A_{\mathrm{s}}$ is the section area of the steel bar, and $\varepsilon_{i}$ is the average strain of the ith section.

The strain gauge results were used for the back-analysis of the pile shaft and base resistances, as discussed below.

3.2.1. Back-Analyzed Pile Shaft Resistance. Table 4 summarizes the back-analyzed unit shaft resistance and the parameters used for the analysis. Figure 8 shows the typical back-analyzed resistance-relative movement curves of the granite residual soil from two tested piles (TP-3 and TP-6). The unit shaft resistances increased rapidly with the relative displacement. The shaft resistance reached its maximum value when the displacement was approximately $10-20 \mathrm{~mm}$. As the displacement was further increased, the shaft resistance remained unchanged or slightly decreased. In other words, the unit shaft resistance was generally fully mobilized at a relative displacement of $10-20 \mathrm{~mm}$, which is equal to $1 \%-2 \%$ of the 
TABLE 3: Loading test results.

\begin{tabular}{|c|c|c|c|c|c|c|}
\hline & $\begin{array}{c}\text { Diameter } \\
(\mathrm{m})\end{array}$ & $\begin{array}{l}\text { Length } \\
(\mathrm{m})\end{array}$ & $\begin{array}{c}\text { Design working load } \\
(\mathrm{kN})\end{array}$ & $\begin{array}{l}\text { Critical failure load } \\
(\mathrm{kN})\end{array}$ & $\begin{array}{c}\text { Max. Applied load } \\
(\mathrm{kN})\end{array}$ & $\begin{array}{l}\text { Max. Settlement } \\
(\mathrm{mm})\end{array}$ \\
\hline TP-1(RDF) & 1 & 8 & 900 & 2464 & 3200 & 80.66 \\
\hline TP-2(RDF) & 1 & 18 & 2000 & 4649 & 5600 & 73.61 \\
\hline TP-3(RDF) & 1 & 23 & 2800 & 7196 & 9000 & 79.52 \\
\hline $\begin{array}{l}\mathrm{TP}-4 \\
(\mathrm{RDC})\end{array}$ & 1 & 8 & 900 & 3608 & 4000 & 51.55 \\
\hline $\begin{array}{l}\text { TP-5 } \\
\text { (RDC) }\end{array}$ & 1 & 18 & 2000 & 5096 & 6300 & 72.35 \\
\hline $\begin{array}{l}\text { TP-6 } \\
\text { (RDC) }\end{array}$ & 1 & 23 & 2800 & 8605 & 10000 & 64.26 \\
\hline
\end{tabular}

Notes: 1. The design working load is based on a geotechnical investigation report and GB50007-2011. 2. The critical failure load is based on Chinese GB500072011, which stipulates that the critical failure load should correspond to a pile head settlement equal to $40 \mathrm{~mm}$.

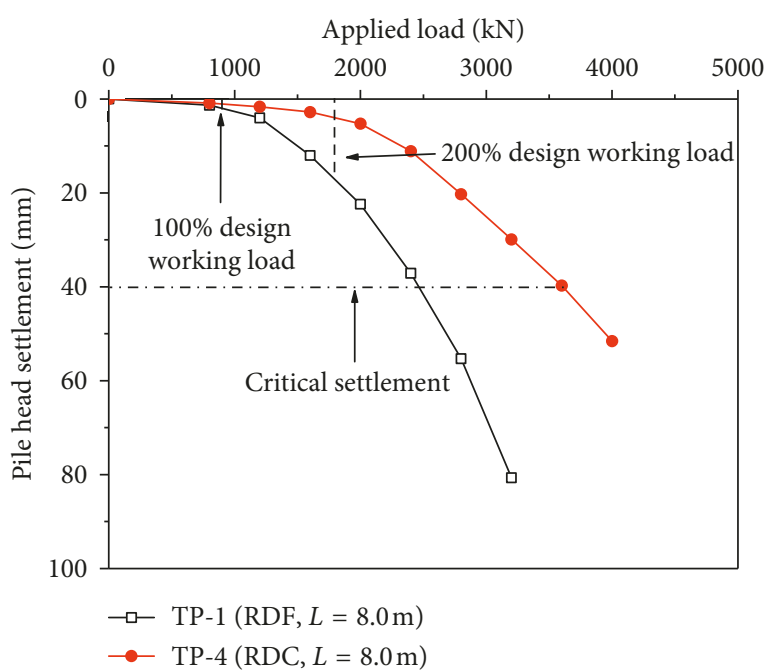

(a)

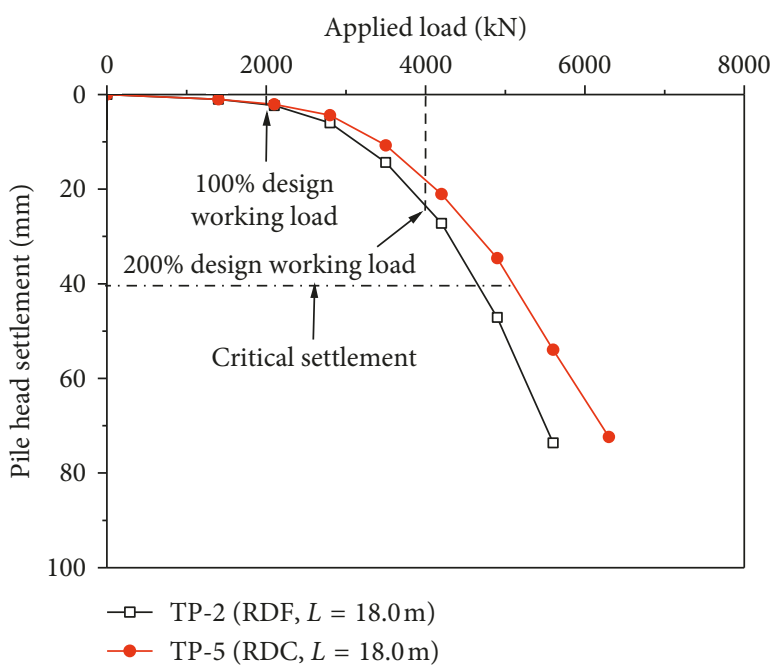

(b)

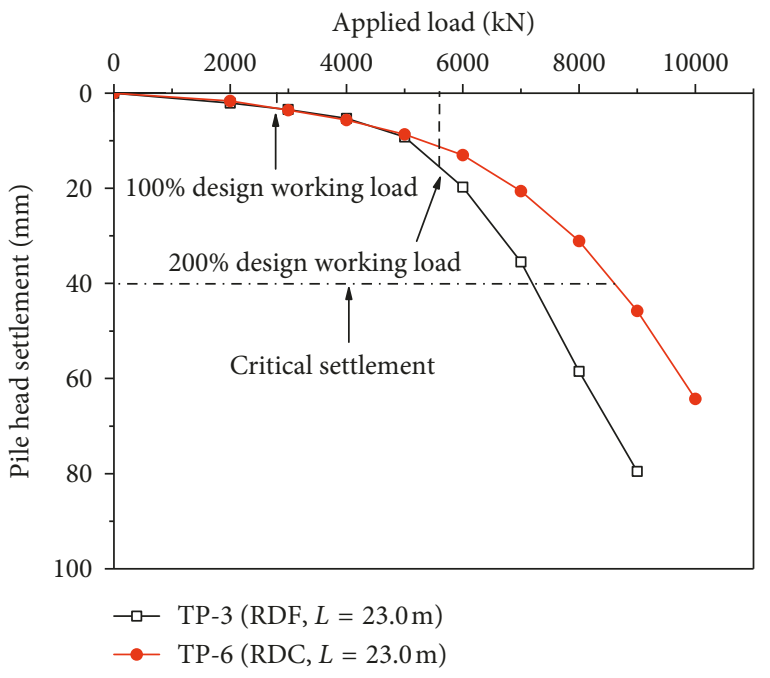

(c)

FIGURE 7: Load-settlement curves for all test piles.

pile diameter. For TP-6, as the displacement was further increased, the shaft resistance generally slightly increased. The shaft resistance of TP-3 conformed to the strain- softening model, while that of TP-6 conformed to the strain-hardening model. This made the curve exhibited by TP-3 generally flatter than that of TP-6, which implicated 
TABLE 4: Summary of back-analyzed factors for the shaft resistance.

\begin{tabular}{|c|c|c|c|c|c|c|c|}
\hline & Depth & $\begin{array}{l}\text { Average SPT-N } \\
\text { blows } / 30 \mathrm{~mm}\end{array}$ & $\begin{array}{l}\text { Undrained shear strength }\left(S_{\mathrm{u}}\right) \\
\mathrm{kPa}\end{array}$ & $\begin{array}{l}\text { Measured ultimate unit skin friction }\left(q_{\mathrm{su}}\right) \\
\mathrm{kPa}\end{array}$ & $q_{\mathrm{su}} / \mathrm{N}$ & $\beta$ & Soil \\
\hline \multirow{2}{*}{$\begin{array}{l}\text { TP-1 } \\
(\mathrm{RD}+\mathrm{S})\end{array}$} & $3-5 \mathrm{~m}$ & 12 & - & 51.95 & 4.33 & 0.77 & GRS \\
\hline & $5-7.5 \mathrm{~m}$ & 16 & 52.22 & 52.12 & 3.26 & 0.50 & GRS \\
\hline \multirow{3}{*}{$\begin{array}{l}\mathrm{TP}-2 \\
(\mathrm{RD}+\mathrm{S})\end{array}$} & $7.5-13 \mathrm{~m}$ & 23 & 75.26 & 74.46 & 3.24 & 0.51 & GRS \\
\hline & $13-17.5 \mathrm{~m}$ & 32 & - & 58.05 & 1.81 & 0.29 & GRS \\
\hline & $17.5-18 \mathrm{~m}$ & 54 & 125.13 & 87.61 & 1.62 & 0.39 & GRS \\
\hline \multirow{6}{*}{$\begin{array}{l}\text { TP-3 } \\
(\mathrm{RD}+\mathrm{S})\end{array}$} & $5-10 \mathrm{~m}$ & 34 & 64.99 & 112.80 & 3.32 & 0.88 & GRS \\
\hline & $10-13 \mathrm{~m}$ & 22 & 79.13 & 52.32 & 2.38 & 0.28 & GRS \\
\hline & $13-16 \mathrm{~m}$ & 23.5 & - & 82.60 & 3.51 & 0.38 & GRS \\
\hline & $16-18 \mathrm{~m}$ & 25 & - & 37.06 & 1.48 & 0.15 & GRS \\
\hline & $18-20.5 \mathrm{~m}$ & 60 & 150.67 & 118.47 & 1.97 & 0.45 & GRS \\
\hline & $20.5-22.5 \mathrm{~m}$ & 73 & - & 65.53 & 0.90 & 0.23 & GRS \\
\hline $\begin{array}{l}\mathrm{TP}-4 \\
(\mathrm{RD}+\mathrm{C})\end{array}$ & $5-7.5 \mathrm{~m}$ & 20 & 65.97 & 98.70 & 4.94 & 0.95 & GRS \\
\hline \multirow{2}{*}{$\begin{array}{l}\mathrm{TP}-5 \\
(\mathrm{RD}+\mathrm{C})\end{array}$} & $5-13 \mathrm{~m}$ & 25.7 & 70.14 & 78.52 & 3.06 & 0.67 & GRS \\
\hline & $13-17.5 \mathrm{~m}$ & 31.5 & 90.26 & 72.26 & 2.29 & 0.41 & GRS \\
\hline \multirow{7}{*}{$\begin{array}{l}\text { TP-6 } \\
(\mathrm{RD}+\mathrm{C})\end{array}$} & $3-7.5 \mathrm{~m}$ & 24 & 56.04 & 96.70 & 4.03 & 1.07 & $\overline{\text { GRS }}$ \\
\hline & $7.5-10 \mathrm{~m}$ & 27 & 72.80 & 110.21 & 4.08 & 0.76 & GRS \\
\hline & $10-13 \mathrm{~m}$ & 31 & 94.42 & 85.49 & 2.76 & 0.50 & GRS \\
\hline & $13-16 \mathrm{~m}$ & 26 & 104.84 & 60.98 & 2.35 & 0.30 & GRS \\
\hline & $16-18 \mathrm{~m}$ & 38 & 134.39 & 106.88 & 2.81 & 0.47 & GRS \\
\hline & $18-20.5 \mathrm{~m}$ & 41 & - & 154.84 & 3.78 & 0.62 & GRS \\
\hline & $20.5-22.5 \mathrm{~m}$ & 57 & 161.61 & 166.26 & 2.92 & 0.61 & GRS \\
\hline
\end{tabular}

GRS: granite residual soil.

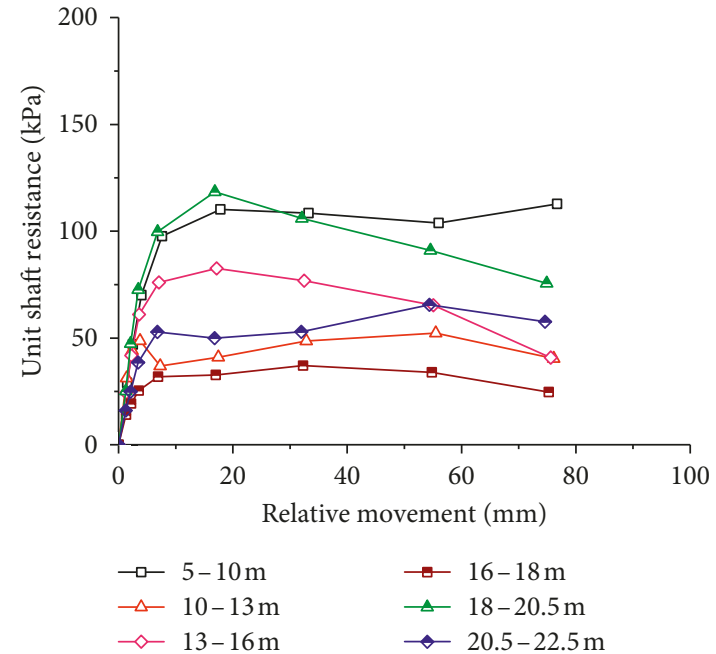

(a)

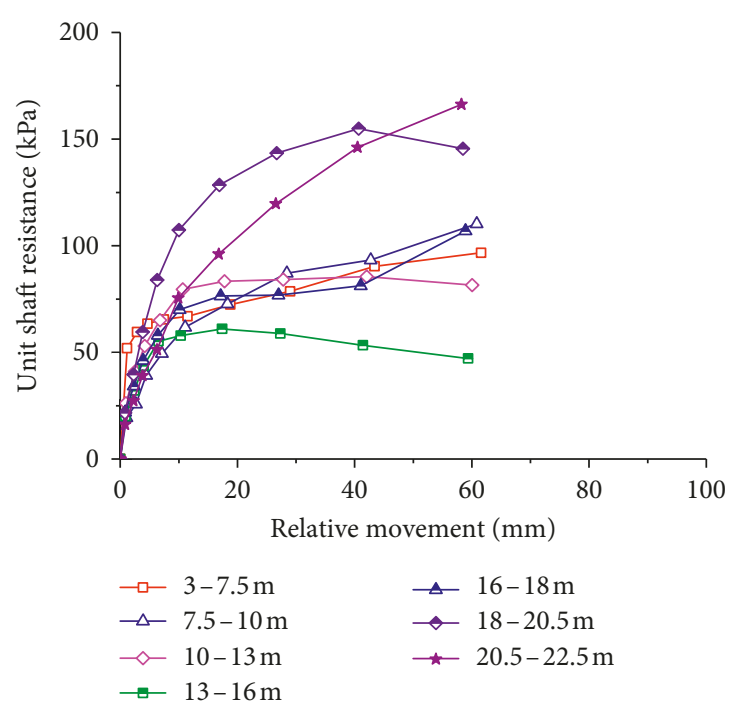

(b)

FIGURE 8: Unit shaft resistance versus the relative movement.

that the bored pile constructed underwater might destroy the structure of the residual soil.

The ultimate unit shaft resistances of TP-6 were generally higher than TP-3 at the same depth, which implies that construction underwater had a more negative effect on the soil shear strength near the pile shaft than piles constructed with casing advanced ahead. This phenomenon also appeared for TP-1 and TP-2 (constructed with bentonite slurry) compared with TP-4 and TP-5. The negative effects of bentonite slurry and water have also been demonstrated by $\mathrm{Ng}$ et al. [19] and Lam et al. [30]. Thus, in addition to the parameters of the residual soil itself, the construction method also has some effect on the pile shaft resistance and should be considered in pile design.

3.2.2. Back-Analyzed Pile Base Resistance. Figure 9 shows the curves of the unit base resistance-pile head settlement for 
all tested piles. The curve of TP-1 shows an obvious turning point at a pile head settlement of $12 \mathrm{~mm}$, which implies a thin "soft cake" of about $10 \mathrm{~mm}$ at the pile toe.

TP-4 and TP-6 (constructed with casing advanced ahead) showed a slightly higher unit base resistance than TP1 and TP-3 (constructed with bentonite slurry and underwater, respectively) under similar conditions. TP-5 (constructed with casing advanced ahead) had a smaller base resistance than TP-2 (constructed with bentonite slurry) because of an intentionally set soft toe for studying its effect on the shaft resistance near the pile base.

In this test, the maximum mobilized base resistances $\left(q_{\mathrm{b}, \max }\right)$ of the six tested piles corresponded to different pile head settlements. For the purpose of discussion, the critical failure base resistance $\left(q_{\mathrm{b}, \mathrm{crit}}\right)$ and ultimate unit base resistance $\left(q_{\mathrm{bu}}\right)$ were used. In order to correspond to the critical failure load used in the previous paragraph, the base resistance at a pile head settlement of $40 \mathrm{~mm}$ was used for $q_{\mathrm{b} \text {,crit. The }}$ ultimate base resistances were estimated with Chin's method [31]. Table 5 presents the values of $q_{\mathrm{b}, \max }, q_{\mathrm{b}, \text { crit }}$, and $q_{\mathrm{bu}}$.

3.3. Back-Analyzed Pile Design Parameters. In the design process, the ultimate pile bearing capacity $\left(Q_{u}\right)$ is generally estimated as follows:

$$
Q_{\mathrm{u}}=Q_{\mathrm{su}}+Q_{\mathrm{bu}}=\mu \sum q_{\mathrm{sui}} l_{\mathrm{i}}+q_{b u} A_{b}
$$

where $Q_{\mathrm{su}}$ is the total ultimate shaft resistance, $Q_{\mathrm{bu}}$ is the total ultimate base resistance, $\mu$ is the pile perimeter, $q_{\text {sui }}$ is the ultimate unit shaft resistance of the $i$ th layer of soil, $l_{i}$ is the pile length in the $i$ th layer of soil, $q_{\mathrm{bu}}$ is the ultimate unit base resistance of the pile, and $A_{\mathrm{b}}$ is the area of the pile base.

The design bearing capacity (working load) is the ultimate load divided by the global safety factor $K$, which is set to $K=2$ in China.

In different design methods, $q_{\text {sui }}$ and $q_{\text {bu }}$ are estimated with different parameters. Because of the lack of calculation parameters for bored piles in granite residual soils by rotary drilling in China, the back-analyzed design parameters of the SPT and effective stress methods were examined.

\subsubsection{Back-Analyzed Design Parameters of the SPT Method.} Figure 10 shows the relationship between the average uncorrected SPT- $N$ values and measured ultimate unit shaft resistance $\left(q_{\mathrm{su}}\right)$ and critical failure unit base resistance $\left(q_{\mathrm{b}}\right.$, crit). The scatter of the $q_{\text {su }}$ results was large, but the data indicated that $q_{\text {su }}$ increases with $N$. The same phenomenon was also demonstrated by $\mathrm{Ng}$ et al. [19] and Chang and Broms [21]. The range of the ratio $q_{\mathrm{su}} / N$ for all piles in granite residual soil was 0.9-4.9. Piles constructed with casing advanced ahead had a higher ratio of $q_{\mathrm{su}} / N(2.3-4.9)$ than piles constructed with bentonite slurry (1.6-4.3). Piles constructed underwater had the lowest ratio (0.9-3.5). These values are fairly higher than non-post-grouted bored piles in granite saprolite that were constructed by grabbing or RCD in Hong Kong $[6,19]$. The measured relationships at this site are close to the well-known relationship $f_{\mathrm{s}}=2 \mathrm{~N}$ that was proposed by Meyerhof for driven piles in sand and has been suggested for bored piles in residual soils in Singapore $[21,32]$. There are four potential reasons for this: (i) the granite residual soil at this site had a higher sand content; (ii) there were some differences in the details of the construction methods (e.g., the bentonite slurry and water in the borehole are relatively static during excavation, which produces less erosion of the borehole wall); (iii) there were some differences in the soil shear characteristic parameters; and (iv) the underground water conditions were different.

Figure 10(b) shows that the critical failure unit base resistances $\left(q_{\mathrm{b}, \mathrm{crit}}\right)$ were much smaller than the estimated ultimate unit base resistance based on Chin's method ( $\left.q_{\mathrm{bu}, \mathrm{e}}\right)$ [31]. The difference in values was caused by the different critical situations: $q_{\mathrm{b} \text {,crit }}$ is at a pile head settlement of $40 \mathrm{~mm}$, while $q_{\text {bu,e }}$ is at a relatively large settlement.

The relationship between $q_{\mathrm{b} \text {,crit }}$ and $N$ can be divided into two parts according to the groundwater conditions near the pile base. Piles with a pile base above the groundwater level (GWL) clearly had a larger slope than piles with a pile base below the GWL. This phenomenon may be caused by the granite residual soil softening and disintegrating underwater $[4,12]$.

At this site, for pile bases above the GWL, $q_{\mathrm{b} \text {,crit }}=35 \mathrm{~N}$. For pile bases below the GWL, $q_{\mathrm{b}, \text { crit }}=15-27 \mathrm{~N}$ with an average value of $q_{\mathrm{b} \text {, crit }}=21.5 \mathrm{~N}$. The average value of all six tested piles was $q_{\mathrm{b} \text {, crit }}=26 \mathrm{~N}$. These values are close to $q_{\mathrm{b}}=$ $30-45 N$, which has been suggested for bored piles in residual soil in Singapore [21]. The back-analyzed value of the estimated ultimate base resistance $\left(q_{\mathrm{bu}, \mathrm{e}}\right)$ was quite large with an average of $q_{\text {bu,e }}=92 \mathrm{~N}$.

For design purposes, the ultimate unit shaft resistance $\left(q_{\text {su }}\right)$ for bored piles constructed by rotary drilling in gravelly granite residual soil (i.e., silty sand according to ASTM D2487 [27]) can be slightly smaller than the tested average values of $3 \mathrm{~N}, 2.5 \mathrm{~N}$, and $2 \mathrm{~N}$ for piles constructed with casing advanced ahead, bentonite slurry and underwater, respectively. For the unit base resistance, $q_{\text {bu }}$ can be taken as $35 \mathrm{~N}$ and $20 \mathrm{~N}$ for pile bases above and below the GWL, respectively, to consider settlement for engineering practice.

3.3.2. Back-Analysis of the Effective Stress Method. The effective stress method is a commonly used design method $[18,32,33]$. In this method, the shaft resistance is calculated as follows when the effective cohesion $\left(c^{\prime}\right)$ is assumed to be negligible:

$$
q_{\mathrm{s}}=K_{\mathrm{s}} \sigma_{\mathrm{v}}^{\prime} \tan \delta_{\mathrm{s}}=\beta \sigma_{\mathrm{v}}^{\prime},
$$

where $K_{s}$ is the coefficient of horizontal pressure, which depends on the relative density and state of the soil, pile installation method, and material, length, and shape of the pile; $\sigma_{\mathrm{v}}^{\prime}$ is the mean vertical effective stress; $\delta_{\mathrm{s}}$ is the angle of friction along the pile-soil interface, which can be taken as the effective friction angle of soil near the pile shaft; and $\beta$ is the shaft friction coefficient.

Table 4 summarizes the results of the back-analyzed $\beta$ values, and Figure 11 shows the $q_{\mathrm{su}}-\sigma_{\mathrm{v}}^{\prime}$ and $q_{\mathrm{bu}}-\sigma_{\mathrm{v}}^{\prime}$ relationships. $\beta$ ranged from 0.15 to 1.07 for all tested piles. It was 0.3-1.07 with an average value of 0.64 for piles 


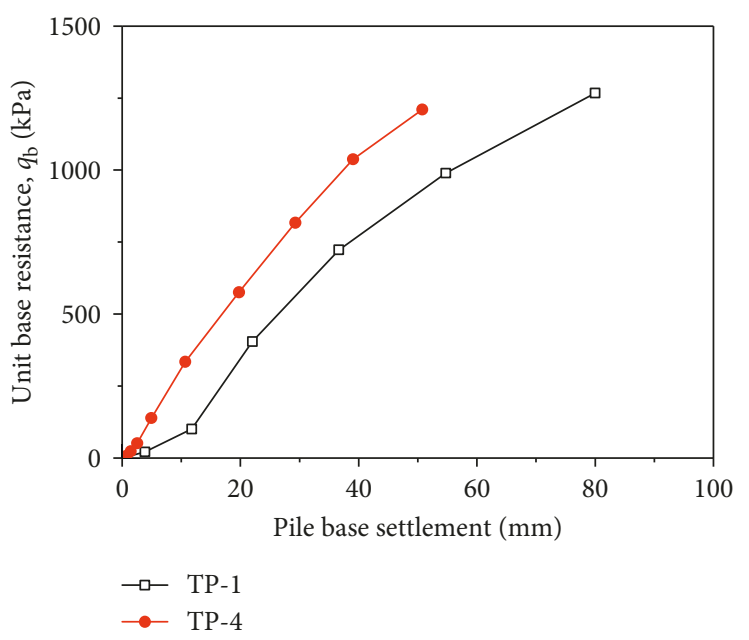

(a)

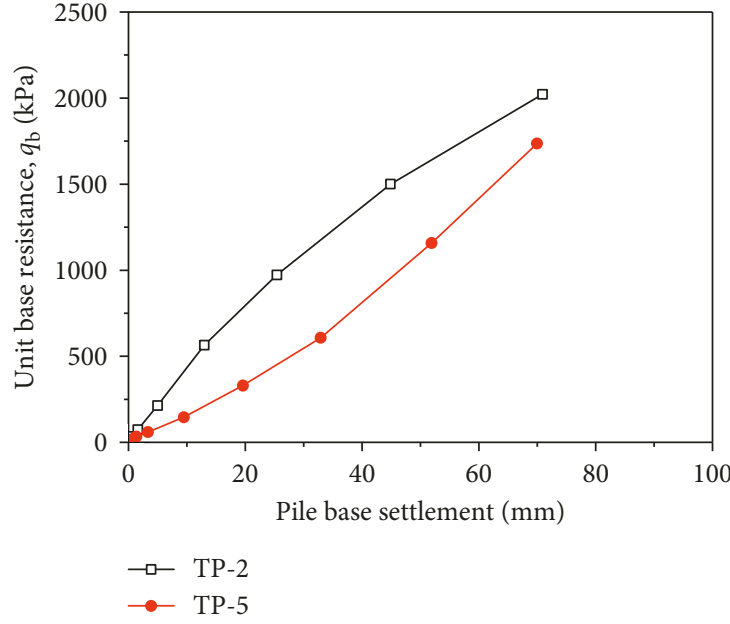

(b)

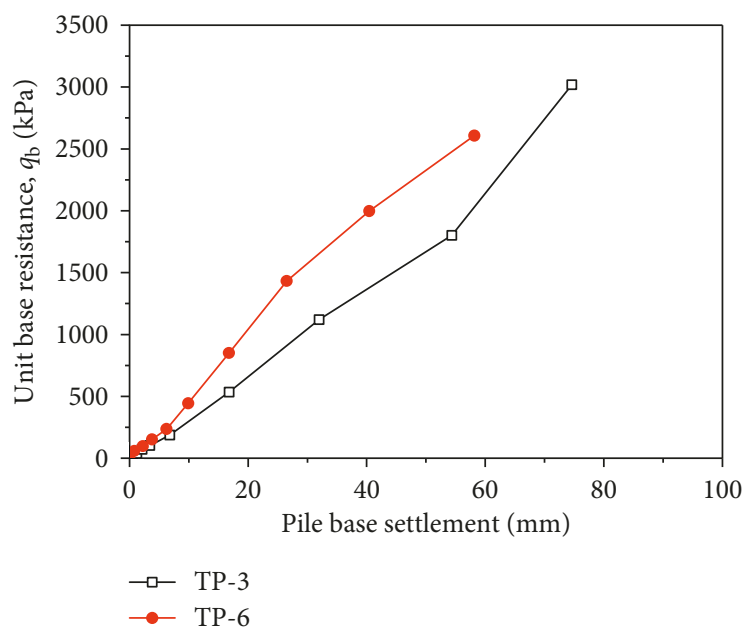

(c)

Figure 9: Measured unit base resistance versus pile head settlement for all piles. (a) TP-1 and TP-4 with $L=8.0 \mathrm{~m}$; (b) TP-2 and TP-5 with $L=18.0 \mathrm{~m}$; (c) TP-3 and TP-6 with $L=23.0 \mathrm{~m}$.

TABLE 5: Unit base resistance $(\mathrm{kPa})$.

\begin{tabular}{lcccccc}
\hline Pile & TP-1 & TP-2 & TP-3 & TP-4 & TP-5 & TP-6 \\
\hline$q_{\text {b, max }}$ & 1268 & 2022 & 3018 & 1210 & 1736 \\
$q_{\text {b,crit }}$ & 772 & 1368 & 1364 & 1052 & 813 & 19807 \\
$q_{\text {bu,e }}$ & 2972 & 3865 & 5536 & 3428 & 4806 & 6101 \\
\hline
\end{tabular}

$q_{\mathrm{b}, \text { max }}:$ the maximum measured unit base resistance; $q_{\mathrm{b}, \text { crit }}$ : the interpreted critical failure resistance at a pile head settlement of $40 \mathrm{~mm}$; $q_{\mathrm{bu}, \mathrm{e}}:$ the estimated ultimate unit base resistance based on Chin's method.

constructed with casing advanced ahead, 0.29-0.77 with an average value of 0.49 for piles constructed with bentonite slurry, and $0.15-0.88$ with an average value of 0.39 for piles constructed underwater. The coefficient $\beta$ of $q_{\text {su }}$ showed a similar trend as the ratio $q_{\mathrm{su}} / N$ for different construction methods. An interesting result is that the average $\beta$ values for piles constructed underwater were slightly smaller than those for piles constructed with bentonite slurry, which completely contradicts prior research [18]. This phenomenon was also demonstrated for the $q_{\text {su }} / N$ ratio. The reason may be the construction method. The traditional RCD method needs debris to constantly be sucked out from the bottom of the hole, so the bentonite slurry or water needs to be circulated continuously, which easily forms a layer of weak cake on the wall of the hole, while RCD underwater does not. For the rotary drilling method, excavated materials are loaded in the drilling bucket directly and then poured onto the ground. The bentonite slurry or water is basically stationary, so almost no weak cake is produced. The main reason is probably that granite residual soil collapses under 


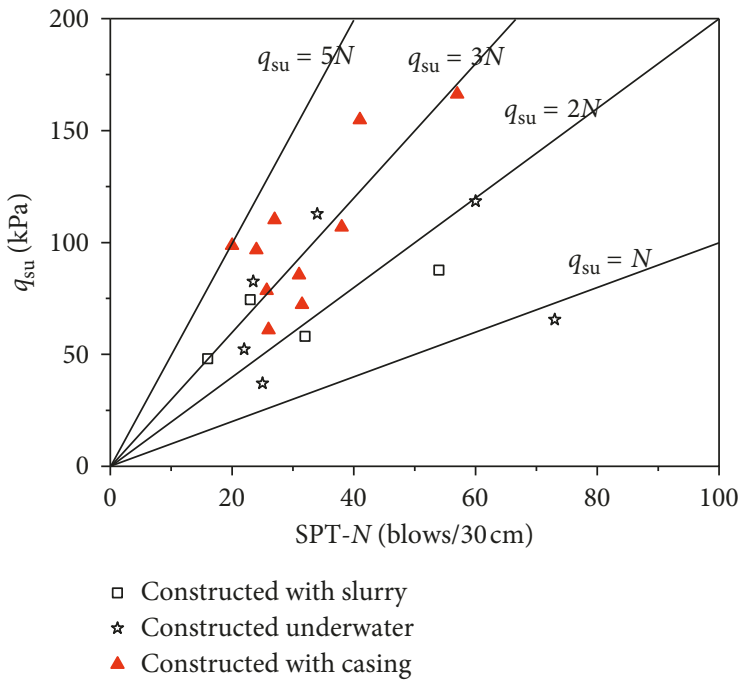

(a)

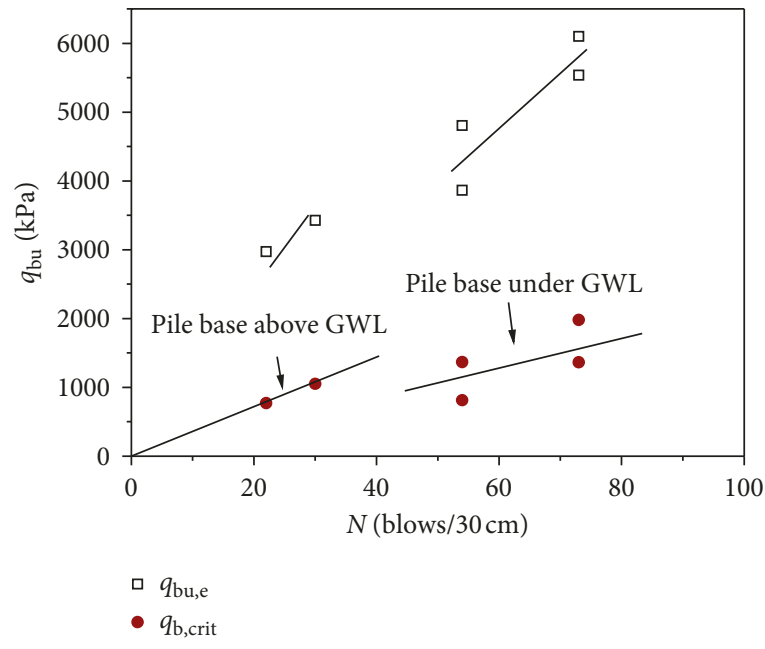

(b)

FIGURE 10: Relationship between SPT- $N$ and the ultimate unit shaft resistance $\left(q_{\mathrm{su}}\right)$ and ultimate unit base resistance $\left(q_{\mathrm{bu}}\right)$ in the granite residual soil of all piles. (a) $q_{\text {su }}$ versus $N$. (b) $q_{\text {bu }}$ versus $N$.

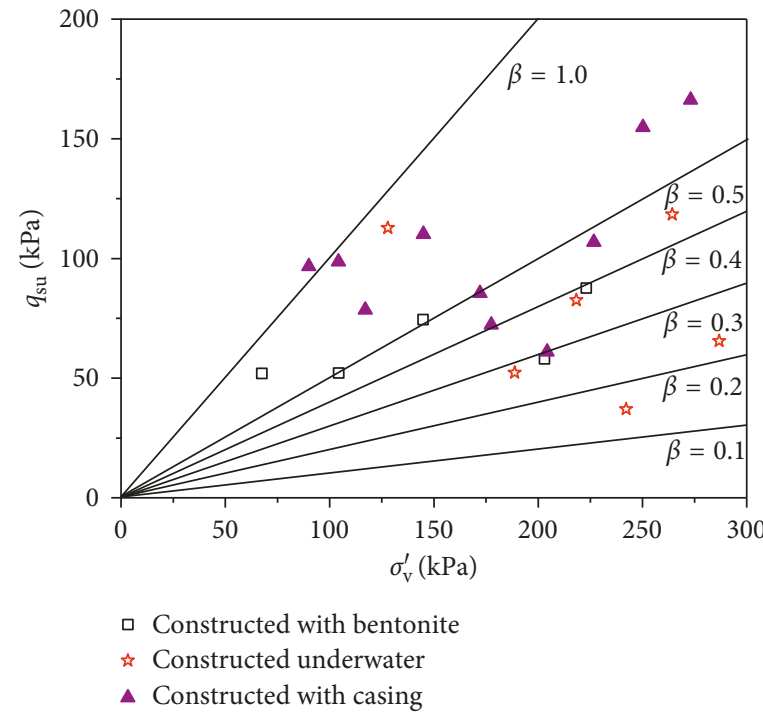

(a)

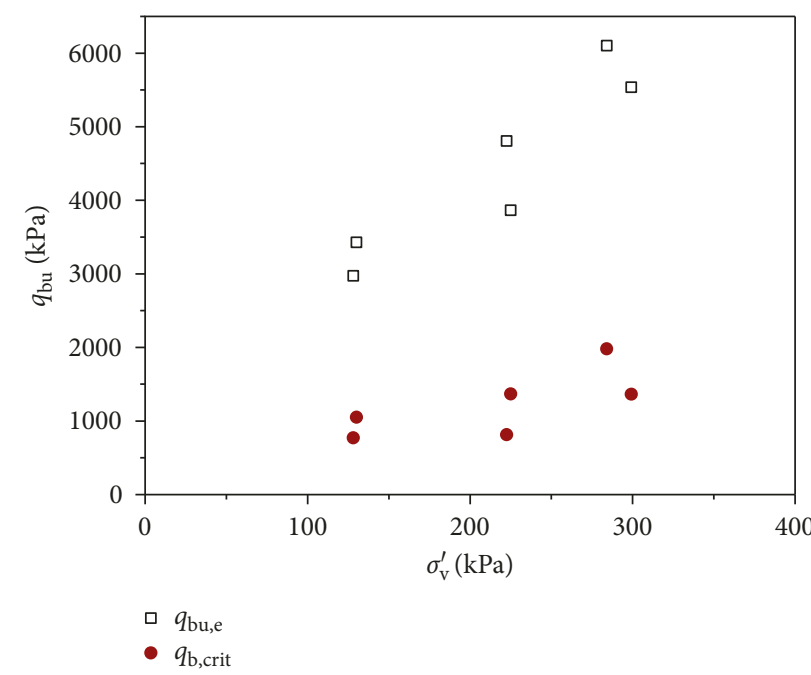

(b)

FIGURE 11: Relationship of the average effective vertical stress $\left(\sigma_{\mathrm{v}}^{\prime}\right)$ with the ultimate unit shaft resistance $(q)_{\text {su }}$ and ultimate unit base resistance $(q)_{\mathrm{bu}}$ in granite residual soil. (a) $(q)_{\mathrm{su}}$ versus $\sigma_{\mathrm{v}}^{\prime}$. (b) $(q)_{\mathrm{bu}}$ versus $\sigma_{\mathrm{v}}^{\prime}$.

the influence of water [34-36]. The combined effects of the above causes may be the reason for the discrepancies between the results of this study and those of $\mathrm{Ng}$ et al. [19].

The relationship between the critical failure unit base resistance $\left(q_{\mathrm{b}, \text { crit }}\right)$ and $\sigma_{\mathrm{v}}^{\prime}$ had a similar trend as the relationship between $q_{\mathrm{b} \text {, crit }}$ and $N$. The coefficient $\beta$ for the base resistance was 3.7-8.0 with an average value of 5.9. If the value of TP-5, which had a pile base that was not completely cleaned, is ignored, the average value of $\beta$ was 6.3. The average value of $\beta$ for the estimated ultimate unit base resistance $\left(q_{\mathrm{bu}, \mathrm{e}}\right)$ was 21.4 .

\section{Conclusion}

A field trial comprising six full-scale instrumented bored piles was carried out at a site in Shenzhen, China, to study the characteristics of granite residual soil for bored pile design. Varying rotary drilling construction techniques were used to install the shafts in an attempt to identify the significance of the installation technique on the performance under an axial load. The key results including the design parameters of SPT method and effective stress method of gravelly granite residual soil were investigated in this study. 
The average back-analyzed shaft resistance design parameters of gravelly granite residual soil at this site for both the SPT and effective stress methods were $q_{\mathrm{su}}=2.9 \mathrm{~N}$ and $\beta=$ 0.52 . These parameters have much higher values than those of previous studies, due to the high gravel content of the granite residual soil. Furthermore, compared with rotary drilling with slurry and underwater, gravelly granite residual soil with construction by rotary drilling with casing advanced ahead indicated a higher $q_{\text {su }}$ based on the result of SPT and effect stress analysis. Besides, gravelly granite residual soil above the groundwater level indicated a higher base resistance with 1.3 to 1.6 times of which under the groundwater level.

Overall, this study provides a series of experimental data on gravelly granite residual soil for rotary drilling piles, which could be helpful for engineering design and construction under similar soil conditions. Limitations and prospects should be noted as follows. First, more data on gravelly granite residual soil should be collected and tested to better verify the proposed finding. Second, further studies on sandy and clayey granite residual soils could be made in the future.

\section{Data Availability}

The load test and strain gauges data used to support the findings of this study are available from the corresponding author upon request.

\section{Conflicts of Interest}

The authors declare that there are no conflicts of interest regarding the publication of this paper.

\section{Acknowledgments}

The field work was provided by Shenzhen Hongyeji Geotechnical Co., Ltd. The authors wish to thank Zhi-Dong Chen (Chairman of Shenzhen Hongyeji Geotechnical Co., Ltd.) and Xin Huang for their kind help. The authors extend their sincere thanks to Prof. Chen Rui of the Harbin Institute of Technology (Shenzhen) for his contributions to certain aspects of the reported investigations. The research described in this study was funded by the Shenzhen Science and Technology Innovation Committee (grant no. JSGG20170413163030692); National Key R\&D Plan-China (grant no. 2016YFC0701502-3); the Ministry of Housing and Urban-Rural Development of the People's Republic of China Science and Technology Projects (grant no. 2016-K5-018); and a Beijing Science and Technology Innovation Leaders Project Grant.

\section{Supplementary Materials}

Supplementary material contains photos of the field trial. Figure S1: photo of Loading test. Figure S2: photo of reinforce bar cage and test instrument. Figure S3: photo of rotary drilling with casing advanced ahead. (Supplementary Materials)

\section{References}

[1] A. L. Little, "The engineering classification of residual soils," in Proceedings of the Seventh International Conference on Soil Mechanics and Foundation Engineering, vol. 1, pp. 1-10, Mexico City, Mexico, 1969.

[2] H. Rahardjo, A. Satyanaga, E. C. Leong, Y. S. Ng, and H. T. C. Pang, "Variability of residual soil properties," Engineering Geology, vol. 141, no. 4, pp. 124-140, 2012.

[3] A. G. Salih, "Review on granitic residual soils' geotechnical properties," Electronic Journal of Geotechnical Engineering, vol. 2012, pp. 2645-2658, 2012.

[4] J. Dai, G. Gao, and T. Wang, "Regional difference of granite residual soil and research on its engineering characteristics," Port Engineering Technology, vol. 46, no. 1, pp. 56-59, 2009, in Chinese.

[5] Q. Wang, D. Tang, Q. Zhang, and J. Zhao, "A study on the structure and composition of granite residual soil in the eastern China," Journal of Changchun University of Earth Science, vol. 21, no. 1, pp. 73-81, 1991, in Chinese.

[6] GEO, Pile Design and Construction, GEO Publication 1/96, Geotechnical Engineering Office, Civil Engineering Department, Hong Kong Government, 1996.

[7] H. Rahardjo, K. K. Aung, E. C. Leong, and R. B. Rezaur, "Characteristics of residual soils in Singapore as formed by weathering," Engineering Geology, vol. 73, no. 1, pp. 157-169, 2004.

[8] GB50007-2011, Code for Design of Building Foundation, Ministry of Housing and Urban-Rural Development of the People's Republic of China, Beijing, China, 2011.

[9] GB50021-2001, Code for Investigation of Geotechnical Engineering, China Architecture \& Building Press, Beijing, China, pp. 84-85, 2009, in Chinese.

[10] DBJ15-31-2016, Design Code for Building Foundation, Construction Department of Guangdong Province, Guangzhou, China, pp. 22-33, 2016, in Chinese.

[11] H. X. Lan, R. L. Hu, Z. Q. Yue, C. F. Lee, and S. J. Wang, "Engineering and geological characteristics of granite weathering profiles in South China," Journal of Asian Earth Sciences, vol. 21, no. 4, pp. 353-364, 2003.

[12] N. Wu, "Study on classification of granite residual soils," Rock and Soil Mechanics, vol. 127, no. 12, pp. 2299-2304, 2006, in Chinese.

[13] JGJ94-2008, Technical Code for Building Pile Foundations, China Architecture \& Building Press, Beijing, China, pp. 33-41, 2008.

[14] DBJ13-07-2006, Technical Code for Building Foundation, Construction Department of Fujian Province, Fuzhou, China, 2006, in Chinese.

[15] SJG01-2010, Code for Investigation and Design of Foundation, Housing and Construction Bureau of Shenzhen, Shenzhen, China, pp. $116-129,2010$, in Chinese.

[16] P. J. Vardanega, E. Kolody, S. H. Pennington, P. R. J. Morrison, and B. Simpson, "Bored pile design in stiff clay I: codes of practice," Geotechnical Engineering, vol. 165, no. 4, pp. 213-232, 2015.

[17] N. Shariatmadari, A. Eslami, and M. Karimpour-Fard, "A new method for estimation the bearing capacity of piles based on SPT results," in Proceedings of 31st DFI Annual Conference on Deep Foundations, pp. 421-429, Washington, DC, USA, 2006.

[18] C. W. W. Ng, T. L. Y. Yau, J. H. M. Li et al., "New failure load criterion for large diameter bored piles in weathered geomaterials," Journal of Geotechnical and Geoenvironmental Engineering, vol. 127, no. 6, pp. 488-498, 2001. 
[19] C. W. Ng, J. H. Li, and T. L. Yau, "Behavior of large diameter floating bored piles saprolitic soils," Soils and Foundations, vol. 41, no. 6, pp. 37-52, 2001.

[20] B. H. Fellenius, J. A. Santos, and A. V. da Fonseca, "Analysis of piles in a residual soil-the ISC'2 prediction," Canadian Geotechnical Journal, vol. 44, no. 2, pp. 201-220, 2007.

[21] M. F. Chang and B. B. Broms, "Design of bored piles in residual soils based on field-performance data," Canadian Geotechnical Journal, vol. 28, no. 2, pp. 200-209, 1991.

[22] D. W. Hight, F. McMillan, J. J. M. Powell, R. J. Jardine, and C. P. Allenou, T. S. Tan, Some characteristics of London clay," in Proceedings Conference Characterisation and Engineering, T. S. Tan, Ed., vol. 2, pp. 851 -907, Singapore, 2003.

[23] W. G. K. Fleming, A. J. Weltman, M. F. Randolph, and W. K. Elson, Piling Engineering, Wiley, New York, NY, USA, 3rd edition, 2009.

[24] P. J. Vardanega, Strength Mobilisation for Geotechnical Design \& Its Application to Bored Piles, Cambridge University Press, Cambridge, UK, 2012.

[25] D. Brown, "Effect of construction on axial capacity of drilled foundations in piedmont soils," Journal of Geotechnical and Geoenvironmental Engineering, vol. 128, no. 12, pp. 967-973, 2002.

[26] M. F. Chang and H. Zhu, "Construction effect on load transfer along bored piles," Journal of Geotechnical and Geoenvironmental Engineering, vol. 130, no. 4, pp. 426-437, 2004.

[27] ASTM D2487-11, Standard Practice for Classification of Soils for Engineering Purposes (Unified Soil Classification System), ASTM International, West Conshohocken, PA, USA, 2011.

[28] ASTM D 1143/D 1143M-07, Standard Test Methods for Deep Foundations under Static Axial Compressive Load, ASTM International, West Conshohocken, PA, USA, 2007.

[29] Q. Zhang and Z. Zhang, "Study on interaction between dissimilar piles in layered soils," International Journal for Numerical and Analytical Methods in Geomechanics, vol. 35, no. 1, pp. 67-81, 2011.

[30] C. Lam, S. A. Jefferis, T. P. Suckling, and V. M. Troughton, "Effects of polymer and bentonite support fluids on the performance of bored piles," Soils and Foundations, vol. 55, no. 6, pp. 1487-1500, 2015.

[31] F. K. Chin, "Estimation of the ultimate load of pile not carried to failure," in Proceedings of the Second Southeast Asian Conference on Soil Engineering, pp. 81-90, Singapore, 1970.

[32] G. G. Meyerhof, "Bearing capacity and settlement of pile foundations," Journal of the Geotechnical Engineering Division, vol. 102, no. 3, pp. 195-228, 1976.

[33] P. J. Vardanega, M. G. Williamson, and M. D. Bolton, "Bored pile design in stiff clay ii: mechanisms and uncertainty," Geotechnical Engineering, vol. 165, no. 4, pp. 233-246, 2012.

[34] M. Aubertin, M. Mbonimpa, B. Bussière, and R. P. Chapuis, "A model to predict the water retention curve from basic geotechnical properties," Canadian Geotechnical Journal, vol. 40, no. 6, pp. 1104-1122, 2003.

[35] N. Wu, "A study on calving property and softening damage parameter of GRS," Journal of Hebei Institute of Architectural Science and Technology, vol. 3, no. 16, 2006, in Chinese.

[36] S. Zhang and H. Tang, "Experimental study of disintegration mechanism for unsaturated granite residual soil," Rock and Soil Mechanics, vol. 34, no. 6, pp. 1668-1674, 2013, in Chinese. 


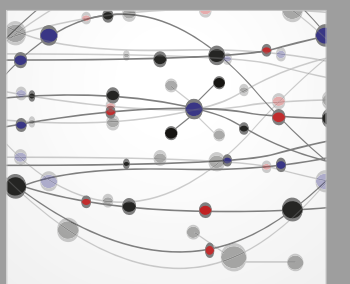

The Scientific World Journal
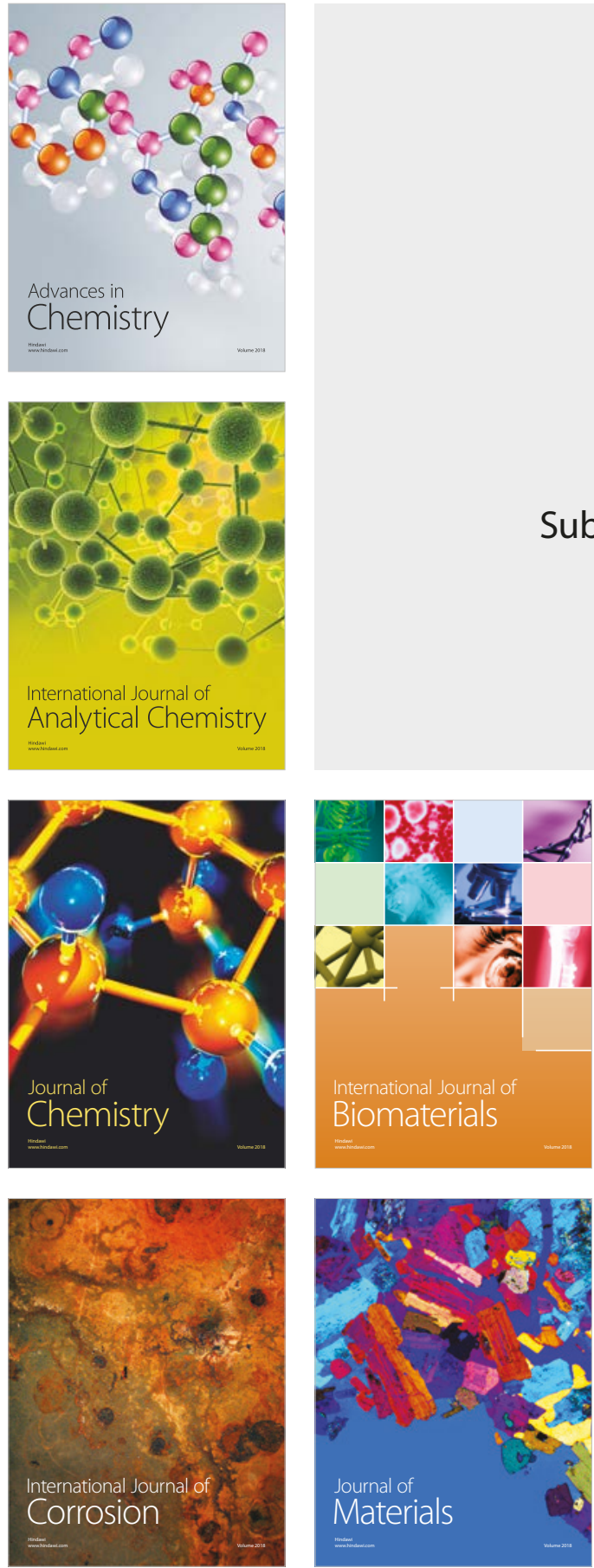

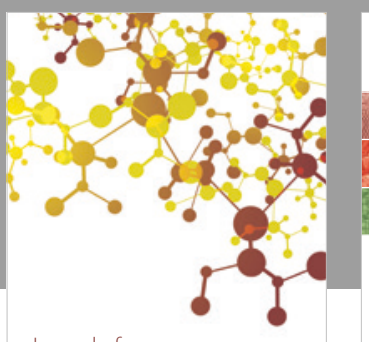

Journal of

Applied Chemistry
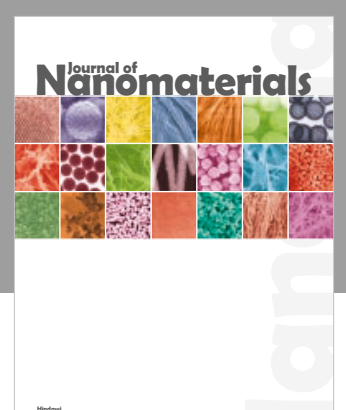

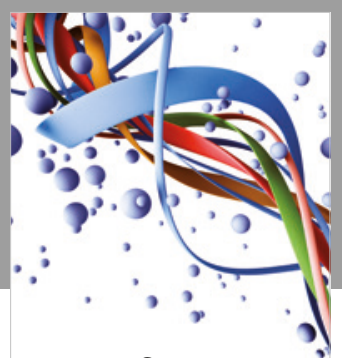

Scientifica

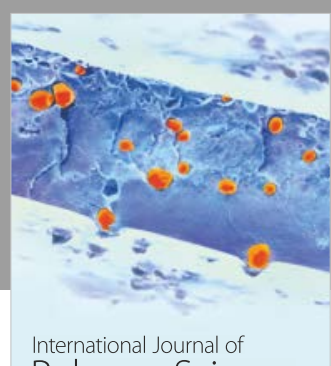

Polymer Science

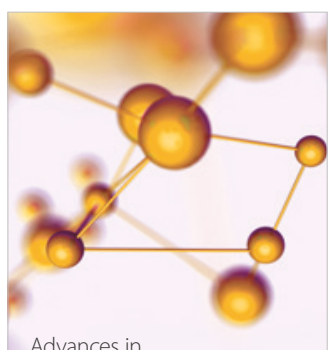

Physical Chemistry
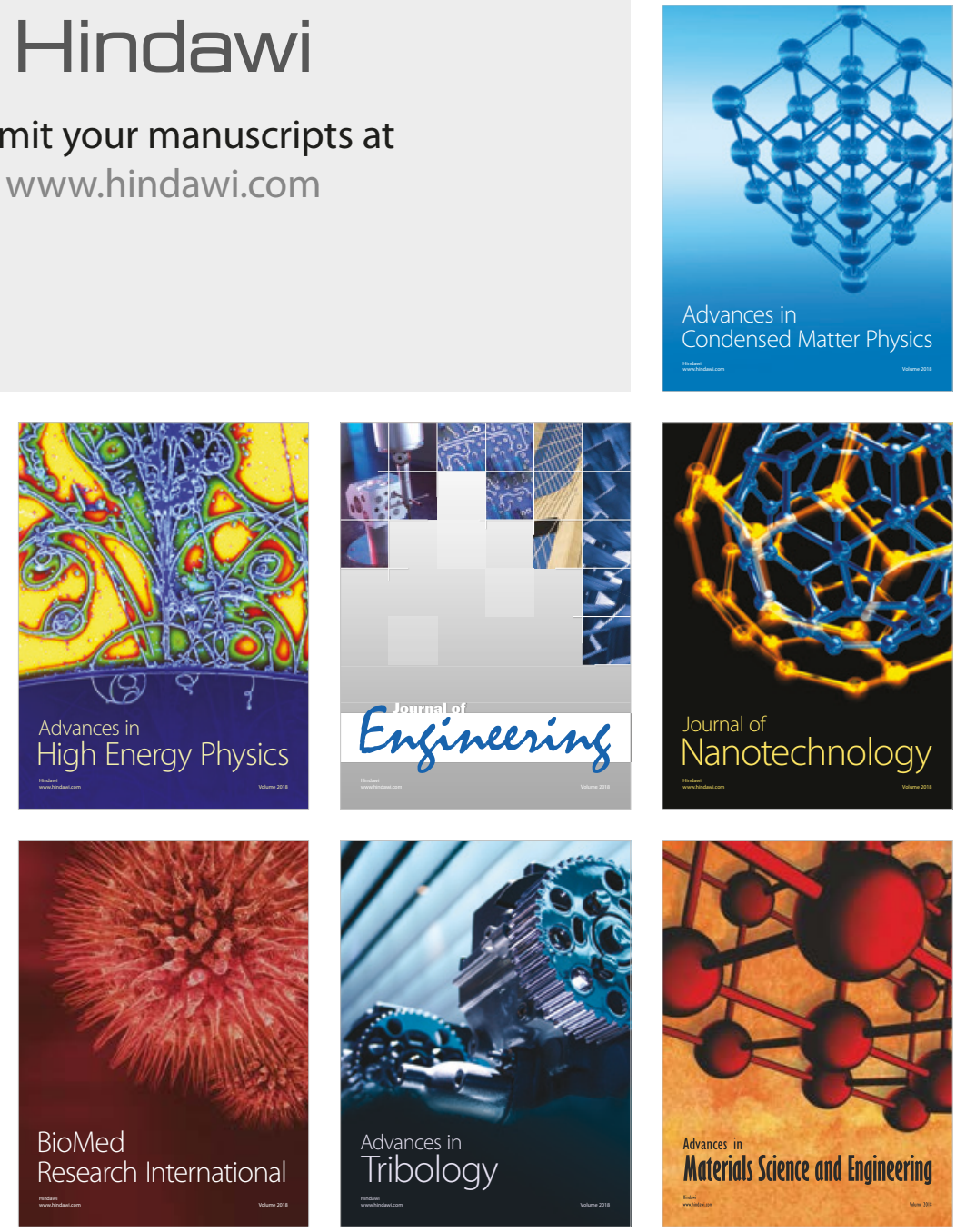